\title{
Фотоприемники лазерного излучения с $\lambda=1.06$ мкм
}

\author{
А.Е. Маричев ${ }^{1)}$, В.С. Эполетов ${ }^{1)}$, Р.В. Левин ${ }^{1)}$, М.З. Шварц ${ }^{1)}$, Б.В. Пушный ${ }^{1)}$ \\ ${ }^{1}$ Физико-технический институт им. А.Ф.Иоффе, Санкт-Петербург, \\ 194021, Политехническая, 26
}

DOI 10.34077/RCSP2019-161

Появление лазеров (оптических квантовых генераторов) способствовало становлению интенсивному развитию новых научных направлений и областей. Одним из таких направлений становится беспроводная передача энергии по оптическому каналу (в атмосфере и по оптоволокну).

Была предложена энергетическая схема преобразователя мощного лазерного излучения похожая на схему полупроводникового лазера на основе двойной гетероструктуры (ДГС), где материал активной области должен иметь ширину запрещенной зоны близкой к краю поглощения квантов излучения $(\mathrm{Eg}-1.17$ эВ $300 \mathrm{~K})$ и прямую структуру зон. Активная зона располагается между слоями с электронной и дырочной проводимостями, аналог лазера, но лазерное излучение характеризуется монохроматичностью и высокой плотность мощности излучения.

Эксперименты по выращиванию были выполнены на установке AIXTRON AIX-200 методом газофазной эпитаксии из металлоорганических соединений на подложках InP n-типа проводимости, ориентированных в плоскости (100) разориентированные на $4^{\circ}$ в направлении (111), при температуре роста $\mathrm{Tp}=600^{\circ} \mathrm{C}$ и давлении $\mathrm{P}=100$ мбар. Поток несущего газа $(\mathrm{H} 2)$ составлял $-\mathrm{Fc}=5$ л/мин. В качестве источников III группы использовались: триметилиндий [TMIn] и триэтилгаллий [TEGa], в качестве источников элементов $\mathrm{V}$ группы: арсин $\left[\mathrm{AsH}_{3}\right]$ и фосфин $\left[\mathrm{PH}_{3}\right]$. В качестве донорной легирующей примеси использовался: силан $\left[\mathrm{SiH}_{4}\right]$ или диэтилтелур [DETe], в качестве источника акцепторной примеси использовался диэтилцинк [DEZn].

На первом этапе проведенных исследований были изготовлены классические фотоэлектрические преобразователи[ФЭП] с p-n переходом и с шириной запрещенной зоны активной области материала $\mathrm{Eg}=1.17$ эВ. Была разработана технология изготовления твердых растворов InGaAsP на подложках InP, которые находятся на границе области спинодального распада .Внешний квантовый выход фотоэлектрического преобразователя достигал $40 \%$ без просветляющего покрытия, спектральный фотоответ достигал $0.45 \mathrm{~A} / \mathrm{BT}$.

На следующем этапе были изготовлены фэп на основе p-i-n структур. На подложке InP n - типа проводимости был выращен буферный (барьерный) слой n-InP легированный DETe c концентрацией $\mathrm{n}-3^{*} 10^{18} \mathrm{~cm}^{-3}$ и толщиной 1 мкм, на нем был выращен слой $\mathrm{n}$-InGaAsP толщиной 100 нм и концентрацией $\mathrm{n}-5 * 10^{17} \mathrm{~cm}^{-3}$ использующийся для понижения барьера. Затем был выращен нелегированный слой InGaAsP толщиной 0.57 мкм и Eg-1.17 эВ использующийся в качестве фотопоглощающего слоя, по верх которого были выращены слои: p-InGaAsP с толщиной до 100 нм и концентрацией $\mathrm{p}-1 * 10^{18} \mathrm{~cm}^{-3}$ и $\mathrm{p}-\mathrm{InP}$ с толщиной равной 1 мкм и концентрацией и $\mathrm{p}-3 * 10^{18} \mathrm{~cm}^{-3} . \mathrm{B}$ качестве подконтактного слоя использовался тройной твердый раствор p-InGaAs толщиной 200 нм и концентрацией $\mathrm{p}-5^{*} 10^{18} \mathrm{~cm}^{-3}$.

Данные приборные структуры проходят процесс литографии для изготовления рисунка и монтажа.

\section{Лumepamypa}

[1] О.Н. Крохин. Передача электрической энергии посредством лазерного излучения, УФН, 176, 441-444.

[2] A.E. Marichev, R.V. Levin, G.S. Gagis and A.B. Gordeeva, Journal of Physics: Conference Series 741

(2016) 012039. 